W stużbie tradycji i odnowy liturgicznej. 50 lat Instytutu Liturgicznego w Krakowie (1968-2018), red. P. Nowakowski, J. Mieczkowski, Kraków 2019, s. 243-261.

ISBN 978-83-7438-849-8 (wersja drukowana), ISBN 978-83-7438-850-4 (wersja online) DOI:http://dx.doi.org/10.15633/9788374388504.19

\title{
For the theology of celebration. Thinking about ars celebrandi 50 years after Vatican II
}

The invitation made by this symposium to revisit the history of the various places of teaching and reflection on the liturgy and its theological approach is an opportunity, not only to remember the masters who preceded us, but also to look at where their theological gaze has led us today. As Bernard de Chartres would say, ${ }^{1}$ in the $12^{\text {th }}$ century, we must recognize that

we are dwarves sitting on the shoulders of giants and if we see more things further away it is not because of the sharpness of our sight and our greatness, but because we are lifted by them.

Through the theological trajectory of the Institut Supérieur de Liturgie (ISL) of the Faculty of Theology - Theologicum of the Catholic University of Paris, we would like to show how the theological and academic

1 Bernard de Chartres cité par Jean de Salisbury, Metalogicon, Documenta Catholica Omnia, 1157, III, 4, 45-50: “Dicebat Bernardus Carnotensis nos esse quasi nanos, gigantium humeris insidentes, ut possimus plura eis et remotiora videre, non utique proprii visus acumine, aut eminentia corporis, sed quia in altum subvenimur et extollimur magnitudine gigantea." 
intuitions that presided over its foundation in 1956, in the wake of the Liturgical Movement of the $20^{\text {th }}$ century, enabled the elaboration and the emergence of a theology of the liturgy starting from a renewed awareness of the ceremoniality. In other words, one of the current tasks in theology of the liturgy is to reflect on the way in which the liturgy makes possible an authentic act of faith.

By placing the liturgy on the horizon of Christian Revelation and the building of the Church, ${ }^{2}$ the Second Vatican Council has become even more entrenched in the exercise of the priesthood of Christ and recognizes a sacramental dimension.

Every liturgical celebration, as a work of Christ the Priest and of His Body which is the Church, is the sacred action par excellence of which no other action of the Church can achieve the same efficiency and effectiveness to the same degree. ${ }^{3}$

However, if the sacraments are to be reflected in the light of the liturgical action of the Church, it is still difficult to define and characterize the elements of a sacramentality of the act of faith that is realized in the context of the liturgy. By following fr. Patrick Prétot, we would then like to explain how this would make liturgy a genuine form of life for the Christian faith.

\section{A theological tradition}

Since its founding in 1956, by Dom Botte in connection with the National Center of Liturgical Pastoral (CNPL) and the Catholic Institute of Paris, the Institute of Liturgy has traced a singular path in theological reflection in liturgy. ${ }^{4}$ Pegged to the Liturgical Movement and thus to different biblical

2 Sacrosanctum Concilium [SC], 2.

$3 \mathrm{SC}_{7}$.

4 Regarding the history of ISL, we will refer to: on the foundation B. Botte, Le mouvement liturgique. Témoignage et souvenirs, Paris 1973, p. 119-135; P. Jounel, P. De Clerck, L'Institut Supérieur de Liturgie de Paris (1956-1981), “La Maison-Dieu” [LMD] 1982 N$^{\circ}$ 149, p. 7-15, with 16-17: the homily of P.-M. Gy pronounced for the 25 years of the ISL; C. Bressolette, Les 40 ans de l'Institut Supérieur de Liturgie, in: La liturgie, lieu théologique, éd. P. De Clerck, Paris 1999, 
revivals, patristic and theological of the $20^{\text {th }}$ century, it reflects the achievements of the liturgy research in light of liturgical science, in the sense of German Wissenschaft but also that the route taken opened and defined new paths. If in its project of foundation, the Institute carried the deep intuition of the Liturgical Movement according to which the liturgical formation would allow, in some ways, a reconquest of the society by a liturgy at the origin of a renewed missionary impulse, today's world has changed and, "becoming a Christian today through liturgy, knowledge of liturgical institutions is necessary but not sufficient." 5 Even more, questioning this "Theological trajectory" not only highlights the operated work but also today's challenges, summed up in the title of the Symposium of the $60^{\text {th }}$ anniversary of the Institute and inspired by the first paragraphs of the Constitution Sacrosanctum Concilium, "Becoming Christian by liturgy." ${ }^{6}$

This theological tradition unfolds according to different time the achievements of wich remain major today still in the courses taught at the ISL.7 The first owes much to Dom Botte, whose intuition was based on the need to have direct access to liturgical sources and to be able to make a critical and scientific study of them. ${ }^{8}$ If the idealization of a period of time remains a risk, and more particularly as far as Christian antiquity ${ }^{9}$ is concerned, the gradual extension of the historical work to the medieval and modern pe-

p. 7-42 (Sciences théologiques et religieuses, 9); P. Prétot, L'Institut Supérieur de Liturgie de Paris, une tradition des études liturgiques, "Archiv Für Liturgiewissenschaft" 58 (2016), p. 102-126.

5 P. Prétot, Accompagner les temps nouveaux. La trajectoire théologique de l'Institut Supérieur de Liturgie depuis 60 ans, LMD $2018 \mathrm{~N}^{\circ}$ 293, p. 136.

6 A. Haquin, Devenir chrétien par la liturgie. Colloque international pour les 60 ans de l’Institut Supérieur de Liturgie (Paris, 3-5 février 2016), LMD 2016 N² 283, p. 143-149.

7 Cf. J. L. Souletie, L'Institut Supérieur de Liturgie et l'héritage du centre de Pastorale Liturgique, LMD $2013 \mathrm{~N}^{\circ}$ 275, p. 47-55; P. Prétot, Accompagner les temps nouveaux. La trajectoire théologique

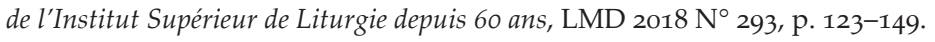

8 B. Botte, Le mouvement liturgique. Témoignage et souvenirs, Paris 1973, p. 121: "[...] the main point in the liturgy course was the commentary on the texts which represent an important part of the tradition of the Church. But to make this comment authoritatively, two things are indispensable: knowledge of liturgical sources and a critical method of work."

9 Cf. R. Taft, L'apport des liturgies d'Orient à l'intelligence du culte chrétien, in: La liturgie, lieu théologique, éd. P. De Clerck, Paris 1999 (Sciences théologiques et religieuses, 9). 
riod allowed to rediscover the long evolutions of the liturgical institutions and their impacts on the life of the Christian people. In doing so, the eye then focuses on conditions of these developments and theirs backgrounds in order to measure more ramifications in contemporary period. While recalling the major contribution of the theological work of Louis Bouyer, ${ }^{10}$ this enrichment was also the major contribution of the Dominican Pierre-Marie Gy ${ }^{11}$ which, as noted by Patrick Prétot, was

more than a historian of the liturgy: he works as a theologian in thinking liturgy "in history" and this attention to the historicity of the liturgy concerns not only institutions but also practices and representations.

Moreover, in the line of "Nouvelle Histoire", Gy was also trying to "value the mentalities that support the practices." 12 Then, this enrichment is based on the study of euchological and patristic texts to better know the roots of the Christian liturgy. In a oecumenically perspective, the comparative study of liturgical institutions was added to these major lines of research and that, by inspiring itself from the huge wealth of the Eastern liturgies. Works of Father Irénée Henri Dalmais ${ }^{13}$ to the writings of Isaïa Gazzola, students learn not only the affiliations but oriental heritage inscribed at the heart of the liturgy, such as in the Eucharistic prayers.

10 Cf. L. Bouyer, Le mystère pascal (Paschale Sacramentum). Méditation sur la liturgie des trois derniers jours de la Semaine Sainte, Paris 1946 (Lex Orandi, 4); B. Lesoing, M. H. Grintchenko et Patrick Prétot, La théologie de Louis Bouyer: du mystère à la sagesse, "Actes du Colloque international", 10-11 octobre 2014, Collège des Bernardins, Institut catholique de Paris, Paris 2015.

11 Cf. P.-M. Gy, Liturgie, Paris 1990 (Liturgie, 2).

12 P. Prétot, L'institut Supérieur de Liturgie de Paris, une tradition des études liturgiques, "Archiv Für Liturgiewissenschaft" 58 (2016), p. 108 \& note 31: “In addition to 'l'école des Annales' founded by Fernand Braudel, Gy will enter into dialogue with historians such as Philippe Ariès, Georges Duby, Jacques Le Goff and Emmanuel Leroy-Ladurie."

13 Cf. I.-H. Dalmais, Initiation à la liturgie, "Cahiers de la Pierre-qui-Vire N.S" 11 (1958); I.-H. Dalmais, Les liturgies d'Orient, Paris 1959 (Je sais - je crois [Dixième Partie], 111); I.-H. Dalmais, Liturgies d'Orient, Paris 1980 (Rites et symboles, 10). Cf. M. Metzger, Irénée-Henri Dalmais, un théologien de la liturgie, LMD $2014 \mathrm{~N}^{\circ}$ 280, p. 117-133. 
In parallel, the arrival in 1967 of Jean-Yves Hameline in the faculty, ${ }^{14}$ proves to the will of Pierre-Marie Gy who succeeded to Dom Botte as director of the ISL, to enrich the theological reflection by joining, with the approaches already mentioned, the contribution of the human sciences and more particularly that of a ritual anthropology. ${ }^{15}$ In a way, he concretized the intuitions expressed in his time by the Dominican Marie-Dominique. Chenu who reminded how much anthropology was necessary to elaborate the ritual act. ${ }^{16}$ Moreover, it offered the possibility of thinking from the liturgy itself, in its most concrete and sensible realization, while maintaining the requirement of a resolutely theological approach. If Dom Botte refused to add the adjective "pastoral" to the name of the institute, it was not to minimize his constitutive importance for the liturgy but rather to call on the one hand, for the respect of its autonomy and on the other hand, to bring out an analysis according to a renewed scientificity that will be described, later, as a "clinical" approach of theology. ${ }^{17}$

These two moments, irrigated by the deepening of the link between bible and liturgy, made it possible to create a third era concerning the elaboration of a theology of the liturgy. From this point of view, the ISL $40^{\text {th }}$ Anniversary Symposium highlighted the developments that had been accomplished

14 Cf. M. Brulin, Poétique de l'action liturgique: Jean-Yves Hameline, anthropologue et théologien de la liturgie, LMD $2014 \mathrm{~N}^{\circ} 279$, p. 13-51.

15 Cf. M. Brulin, Le parcours d'anthropologie à l'Institut Supérieure de Liturgie, 1966-1997, in: La liturgie, lieu théologique, éd. P. De Clerck, Paris 1999, p. 177-187 (Sciences théologiques et religieuses, 9): "He is the inspirer of a wide interdisciplinary course whose objective is, in particular, to elaborate the teaching of a ritology, itself located in a more general effort of comprehension of the Christian worship, the liturgy, the ritual and sacramental practices. Indeed, if the notion of ritual is not religious itself, it is difficult to think of a religion without ritual."

16 Cf. M.-D. Chenu, Anthropologie et liturgie, LMD $1947 \mathrm{~N}^{\circ}$ 12, p. 53-65; Les sacrements dans l'économie chrétienne, LMD $1947 \mathrm{~N}^{\circ}$ 12, p. 53-65; Anthropologie de la liturgie, in: Vatican II, La liturgie après Vatican II, éd. J.-P. Jossua, Y. Congar, Paris 1967, p. 159-177 (Unam Sanctam, 66).

17 Cf. H.-J. Gagey, La théologie: une attitude clinique fondamentale, "Transversalités" 2017 N 143, p. 15-36; La tâche clinique de la théologie, in: La responsabilité des théologiens. Mélanges offerts à Joseph Doré, éd. F. Bousquet et al., Paris 2002, p. 705-721. 
and could then draw new perspectives for research. ${ }^{18}$ It dealt with taking into account the transition that was taking place between liturgical science that examined this in a certain way from the outside, as an object of study and analysis, to an intelligence of the liturgy which is not only within the liturgical "material" (texts...) but also which considers it as a living reality, a genuine way of living the faith. This evolution was somehow in nuce in the first issues of the Constitution Sacrosanctum Concilium. Because the liturgy is the exercise of the priesthood of Christ who "always associates the Church, his beloved Bride, who calls to her Lord and through him, offers worship to the eternal Father," 19 it deploys Christian Revelation according to a ceremonial logic in order to build up the Church as "a holy temple in the Lord, a habitation of God in the Spirit [...] [and] as a signal raised on the nations." Moreover, the liturgy takes a true sacramental dimension, not only because it is their own place of celebration, but because it follows the same theo-logic. ${ }^{20}$

This vision is wisely highlighted by the work of Louis-Marie Chauvet who, through his publications, will continue to promote a true sacramental hermeneutics of the Christian life. ${ }^{21}$ But also by those of the three successive

18 Cf. La liturgie, lieu théologique, éd. P. De Clerck, Paris 1999, p. 201-230 (Sciences théologiques et religieuses, 9). In particular, we will focus on the contribution of the director of the ISL from 1986 to 2001, where he sets out the challenges of such a definition "the liturgy as a theological place" and that of L.-M. Chauvet "the liturgy tomorrow: prospective essay," whose analysis remains relevant today.

$19 \mathrm{SC}_{7}$.

20 SC 2: "For the liturgy, through which the work of our redemption is accomplished, most of all in the divine sacrifice of the Eucharist, is the outstanding means whereby the faithful may express in their lives, and manifest to others, the mystery of Christ and the real nature of the true Church. It is of the essence of the Church that she be both human and divine, visible and yet invisibly equipped, eager to act and yet intent on contemplation, present in this world and yet not at home in it; and she is all these things in such wise that in her the human is directed and subordinated to the divine, the visible likewise to the invisible, action to contemplation, and this present world to that city yet to come, which we seek."

21 Cf. Symbole et Sacrement, une relecture de l'existence chrétienne, Paris 1987 (Cogitatio Fidei, 144) and Le corps, chemin de Dieu, Paris 2010. 
directors of ISL, Paul de Clerck, Patrick Prétot and Jean-Louis Souletie. ${ }^{22}$ However, while the theological development of Sacrosanctum Concilium places the sacraments in the liturgical "site", yet it is still difficult to define and characterize the elements of a sacramentality of the act of faith that is realized in the cultual context. It is the horizon of theological work of the Institute of Liturgy nowadays. It is concretized in the work led by Gilles Drouin, ${ }^{23}$ current director of the ISL, as well as those of Hélène Bricout ${ }^{24}$ or Sr. Bénédicte Mariolle. ${ }^{25}$

\section{The "site cérémoniel" as a hermeneutic tool in liturgy}

We are now in a new phase of the reception of Sacrosanctum Concilium, after the first moments where the various Liturgical Institutes around the world for the elaboration and reflection of its concrete implementation were engaged. This rapid journey of a tradition of liturgical research is a testimony of the evolution and enlargement of the liturgical sciences, but also to a renewed approach to the liturgy. In other words, the various achievements of this work make it possible to grasp the liturgy as ars celebrandi, as art and craft. ${ }^{26}$ Saying so means leaving from a fragmentary, quasi-punctual vision of rites, gestures or words of the liturgy, in order to approach it in its "canonical" closing of total action, in its celebration itself which is the liturgy. In a way, it means hearing the discrepancy suggested by the injunction "there is the model of the practice and the practice

22 P. De Clerck, L'intelligence de la liturgie, Paris 1995 (Liturgie, 4); P. Prétot, L'adoration de la croix, Paris 2014 (Lex Orandi - Nouvelle serie, 2); La liturgie, une piété moderne, dir. J.-L. Souletie, Paris 2016.

23 G. Drouin, Offrir avec le peuple, offrir pour le peuple? Une question liturgique post-tridentine, LMD 2018 N²91, p. 167-188 and De Saint-Sulpice à Saint-François de Molitor: du théâtre divin à l'assemblée célébrante, LMD $2018 \mathrm{~N}^{\circ}$ 292, p. 107-120.

24 H. Bricout, Le mariage, entre consentement et bénédiction: le sacrement et son ministre, Paris 2015 (Lex Orandi - Nouvelle Série, 4).

25 B.-M. de la Croix Mariolle, La pastorale des sacrements: éléments de réflexion pour un discernement, LMD $2016 \mathrm{~N}^{\circ} 284$, p. 141-173.

26 Cf. F. Cassingena-Trévedy, La liturgie, art et métier, Genève 2007. 
of the model." The ceremoniality, the extent of the faith lived and celebrated by the Church can be found between these two main ideas. In other words, God is liturgically knowable and perhaps it is the most accurate way to know him humanly, by the experience of worship. It is therefore not a question of a faith put into liturgical practice, nor of a theology in the habit of prayer, but the very life of faith irrigated by listening to the Word of God and nourished by the Eucharistic bread. This is why we can recognize the liturgy as "form of life." And as Prétot notes,

On this point, moreover, research in anthropology of the liturgy, especially those of Jean-Yves Hameline [...], draw attention to what "works" in the liturgical life. The liturgy is a complex act that constantly combines rites and words: it is not primarily a text but an action that comes from the 'Word of God.'27

Also, inspiring by the notion of site cérémoniel elaborated by this theologian, ${ }^{28}$ we would like to explore this combination as an original and successful way of thinking about the ars celebrandi for today.

It is not useless to begin by recalling that for the closing conference of the Faculty of Theology of the centenary celebrations of the Catholic Institute of Paris held in December 1990, Jean-Yves Hameline was the representative of the Institute of Liturgy. In a round table discussion where one wondered about the way of doing theology in the age of the human sciences, he exposes the necessary passage, and of which the liturgy is at once the place and the means, thus the mediation in the fullest sense of the term. It means going from the anthropological idea to the anthropological experience, ${ }^{29}$ that is to say, starting from the human experience in order to return to it

27 P. Prétot, L'institut Supérieur de Liturgie de Paris, une tradition des études liturgiques, "Archiv Für Liturgiewissenschaft" 58 (2016), p. 107.

28 J.-Y. Hameline, Une poétique du rituel, Paris 1997, p. 100 (Liturgie, 9): the 'site cérémoniel' is "une composition de données in praesentia, et institution du lieu"; J.-Y. Hameline, Note pour un concept de site cérémoniel, "Concilium" 259 (1995), p. 63-67, citation p. 63: it is "une composition in praesentia de données comportementales, et institution du lieu, comme don de la place et activité mémorielle."

29 J.-Y. Hameline, Faire de la théologie à l'heure des sciences humaines, participation à la Table ronde animée par Xavier Thévenot, in: Les cent ans de la faculté de théologie UER de Théologie et 
better through the liturgical experience and to discover the fullness of our own believing identity. Also, reaching a true theological anthropology of liturgy by his great knowledge in the field of musical practices, worship ${ }^{30}$ and ritology,,$^{3^{1}}$ he will show interest in such a ceremonial approach.

For this matter, it is first necessary to distinguish both the ceremonious of the ceremonial as "what arises in the difference [...] between engaging in a scene and engaging in the production of its effects." He wants to go beyond a sort of formal break between a theory of worship and its implementation. Far from promoting an aestheticism or a cold formalism in liturgy, he on the contrary invites us to pay attention to its indecisive and graduated dimension in order to experience it as a time of space in which, in sheer action, God is revealed while veiling. This ceremonial reinvestment relies on a fine articulation between the place given back to the body, the signs and gestures as well as to the words, but also to the ritual action itself. It is at this price that the liturgy can become an authentic worship:

\footnotetext{
The cult is etymologically 'maintenance', care, more than ostentation or cautious operationality. Nowadays it would consist of giving to things time to happen, which supposes to stand at equal distance from the restraint (haste, worry, pressure...) and the casualness (mechanical routine, easy effects and cheap fakings...). The happy time would be that of an availability to things, a 'sufficient' investment, of a mild excitement and especially of a receptivity comparable in a certain way to the physiology of the smile. ${ }^{22}$
}

de Sciences Religieuses ICP, dir. J. Doré, Paris 1992, p. 155 (Sciences Théologiques et religieuses, 1).

30 A volume, to be published by Brepols under the direction of Cécile Davy- Rigaux, will bring together all her publications in musicology and on the place of actio canendi in Christian worship; cf. J.-Y. Hameline, Cérémonies, cérémonial, cérémoniaux dans la catholicité post-tridentine, in: Les Cérémoniaux catholiques en France à l'époque moderne, dir. C. Davy-Rigaux, B. Dompnier, D. O. Hurel, Turnhout 2009, p. 11-42 (Église, Liturgie et Société dans l’Europe moderne, 1).

31 J.-Y. Hameline, Une poétique du rituel, Paris 1997 (Liturgie, 9) \& Petite poétique des arts sacrés, Paris 2014 (Lex Orandi - Nouvelle Série, 3).

32 J.-Y. Hameline, Observations sur nos manières de célébrer, in: J.-Y. Hameline, Une poétique du rituel, Paris 1997, p. 47 (Liturgie, 9). 
Hameline, however, is aware of the difficulty: it deals with finding a theologically based understanding of ceremoniality, that is to say of the liturgy seen as total action. The risk remains to oscillate between a ceremonial excess or the rubricism. Therefore, we may assume that if the ceremonial frame amplifies after Trent, it is to better compensate a kind of focusing on the celebration's sacramental core considered the only true action. In addition, if the liturgical reform initiated by the Second Vatican Council made us relativized a ceremonial language, we haven't totally given up on this focus on the sacramental core. ${ }^{33}$ As per our theologian, a correct conception of ceremoniality should enable the theology of the faith to be liturgically deployed.

The liturgy remains fragile because of the risks it can take on the side of 'ceremoniality', which is something other than 'ceremonial'. It is fragile too, in reverse, by the 'vibratility' of the signs it employs the stained glass, sensitive to the light and the hours of the day, the space we occupy, the place marked and the occupied place, but occupied how? ${ }^{34}$

By forging the notion of site cérémoniel, which is both a heuristic and theological tool for grasping the liturgical and ritual functioning beyond a simple succession or juxtaposition of words, gestures and attitudes, he wishes to highlight interrelationships between the different liturgical "things" (people, places, rites, materials). At the same time, this notion involves a hermeneutical process on the "things" considered, making them "appear" as a condition of possibility of an act of faith. The site cérémoniel thus enables, by this double dynamism, to characterize the way of "taking place" by the liturgy, to be situated not only in a space and a time, but

33 T. Pott, Explorer les contours de la sacramentalité: la liturgie entre la réalité de la vie et la vérité de la foi, LMD $2018 \mathrm{~N}^{\circ}$ 292, p. 80: "Les sacrements, dans toute leur dynamique, sont enracinés dans la sacramentalité de la liturgie dont ils sont les clés de voute. Il est extrêmement urgent que ce lien existentiel soit redécouvert et puisse reprendre vie. Car ce n'est que dans la sacramentalité de la liturgie, présence du Salut qui se dévoile et se communique sur le mode de célébration, que les symboles vitaux qui constituent les sacrements, en tant que mysterion du Salut, peuvent être revivifiés par cet Esprit qui descend dans l'homme vivant aujourd'hui." 34 J.-Y. Hameline, Patrice de la Tour du Pin et l'esprit de la Liturgie, in: Patrice de la Tour du Pin: La Quête de la joie, au cour d'une somme de poésie, éd. I. Renaud-Chamska, Paris 2003, p. 50. 
even within a believing relationship. As a kind of evidence, for him, the Eucharistic celebration is by nature the high place of this existential and believing localization. ${ }^{35}$

By forging the term illocatoire from the illocutionary word according to Austin's theory, he wants to translate the capacity of a ritual action to be within a place, but even more so in the heart of a place, a network of meanings, and especially in the heart of faith. The purpose of the liturgy is thus to place the faithful believer in the very heart of an alliance between God and men. Alliance that she continues to announce, to say and to give through her act both religious and sacramental. Hameline recall the thus not only relevant, but the irreplaceable nature of the liturgy so that the act of faith is located in theology in the most accurate way. This liturgical body is then conceived as a place of confirmation and authentication of faith. The site cérémoniel is to understand not as a place but as a process, a signifying production that allows the faithful to believe and become believer. ${ }^{36}$ Indeed it has to do with

the act of theology in order to try discerning what comes from and enlights from the act of faith as movement, attitude, self-movement and self-image, in ritual and sacramental actions and, more generally, in the exercise of Christian liturgy. ${ }^{37}$

35 J.-Y. Hameline, À la recherche d'une économie postorale, LMD 2006 N² 247, p. 51: “L'échange eucharistique est à la fois le modèle et l'inducteur de toute économie illocatoire."

36 J.-Y. Hameline, À la recherche d'une économie postorale, p. 52: "Il s'agit bien de 'se trouver là': prendre place et composer au milieu des signes comme signe sacré, et de s'y reconnaître, voire de s'y découvrir. Et, dans cette économie, ce que nous appelons 'le corps' se révèle l'organon décisif d'une connaissance première, qui articule le présent fugitif et l'être-là sur une promesse de reconnaissance future. La liturgie, comme une sorte de matin des choses, ne dit-elle pas quelque peu, dans sa capacité de préfiguration eschatologique: 'Viens connaître comme tu es connu."'

37 J.-Y. Hameline, La foi sur son axe fondamental, in: J.-Y. Hameline, Une poétique du rituel, Paris 1997, p. 11 (Liturgie, 9). 


\section{A theology of ceremoniality}

This reassessment of the ceremoniality, linked to a theology of action in liturgy based on the concept of site cérémoniel, can highlight what had been sketched by Sacrosanctum Concilium 7 through the category of "presence." ${ }^{38}$ In designating the various modes of presence of Christ to his Church, especially in the liturgical action, the conciliar text thus eminently qualified the fruits of the exercise of the priesthood of Christ, while inscribing it beyond the mere liturgical setting. ${ }^{39}$ Thinking the ars celebrandi from the perspective of ceremoniality can help characterize the present setting process wich edifies the faithful person as a believer and makes them fall within a relationship with the Lord and with his brothers. Three dimensions can characterize the contribution of such a theological elaboration of ceremoniality allows so much to describe the liturgy as "form of life."

\section{Anthropological dimension}

First of all, it has to do with granting a truly anthropological approach to the liturgy. It is basically a human reality and must be apprehended as such. It has nothing to do with subordinating theology to human science, ${ }^{40}$

38 SC 7: "To accomplish so great a work, Christ is always present in His Church, especially in her liturgical celebrations. He is present in the sacrifice of the Mass, not only in the person of His minister, 'the same now offering, through the ministry of priests, who formerly offered himself on the cross', but especially under the Eucharistic species. By His power He is present in the sacraments, so that when a man baptizes it is really Christ Himself who baptizes. He is present in His word, since it is He Himself who speaks when the holy scriptures are read in the Church. He is present, lastly, when the Church prays and sings, for He promised: 'Where two or three are gathered together in my name, there am I in the midst of them"' (Mt 18:20).

39 SC 9 and Paul VI in Mysterium Fidei (1965): "Il est présent à son Église qui accomplit les œuvres de miséricorde [...]. Il est présent à son Église qui prêche [...]. Il est présent à l’Église qui dirige et gouverne le Peuple de Dieu [...]."

40 J.-Y. Hameline, Faire de la théologie à l'heure des sciences humaines, p. 154: "Je suis tenté, en ce point, de faire l'éloge d'une science partielle, et à mi-chemin, qui éprouve et déplace le langage naturel, qui suspend, ou tout au moins retarde la pulsion à interpréter, et constitue à 
let alone turning these latter into simple auxiliary sciences to theology. In fact it deals with inspiring oneself from anthropological data in order to obtain a theology that does not just remain in a subject / object or theory / practice relationship as far as the faith and its experience is concerned, but also reveals its theological and anthropological continuity.

If the liturgy is based on a dynamic process, which does not separate fides qua creditur and fides quae creditur, but instead articulates and unites them "from its anchor in the determinations of the common human condition," then it gives birth to a common faith. It is defined as

the general condition of human existence that could express by saying that there is no possibility for a human subject to come to the place which constitutes him such, that by a kind of rental pact which is, in its proper ratio, entirely of the order of faith.42

Because liturgy is a passage through a sensitive intelligence of faith, it is not so much a prerequisite as the human situation in which a genuine act of faith can be realized. This anthropological dimension is adequate to the nature of the liturgy, to its ceremonial deployment and assumes the request, expressed in his time, by Chenu:

\footnotetext{
We can only engage the sacrament in consubstantiality with man. The two words 'anthropology' and 'sacramental' are inseparable from each other not only in terms of methods but constitutively.43
}

nos yeux tout au moins, outre une boîte à outils analytiques aisément transposables, la base indispensable à ce que Jacques Audinet appelait une expertise."

41 J.-Y. Hameline, La foi sur son axe fondamental, p. 12.

42 J.-Y. Hameline, La foi sur son axe fondamental, p. 13.

43 M.-D. Chenu, Pour une anthropologie sacramentelle, LMD $1974 \mathrm{~N}^{\circ} 119$, p. 86. 


\section{Biblical dimension}

Next, because the liturgy is based on the principal dialogue between God and his creature, ${ }^{44}$ starting from ceremoniality allows the conditions and the nature of this dialogue to be justified by a biblical theology of the act of faith. Confessing the divine name is in a way the summary between listening and expressing faith, given that it places us between traditio and confessio. 45 In other words, if no one has ever seen God and it could ultimately remain the deus absconditus of the Old Testament, the proclamation of the Name of Jesus Christ enables us not only to enter into a liturgical knowledge of God but, at the same moment, to already taste its presence. By following St Paul for whom "fides ex auditu" the transmission of faith through the liturgy is not a theological concept but the very dynamics of the believing experience. So in 1 Col 11, Paul does not convey a dogma or a concept to the community of Corinth, but a salvation dynamic. This must define, not only their lives as believers, but also the community itself like ecclesia by distributing the places to the participants, and thus their mission. ${ }^{6}$ By focusing on the ceremoniality, Hameline is not interested in ceremoniality in itself but in what it reveals about the link between liturgy and life, and the way in which the mystery arises and unfolds in a human life. Thus, she can become truly Christian, in the ontological sense of the term.

\footnotetext{
44 Cf. E. Bianchi, G. Boselli, L'Évangile célébrée, Bruxelles 2018 (La part-Dieu, 33).

45 J.-Y. Hameline, La foi sur son axe fondamental, p. 17: "La foi ne connaît pas son objet autrement que comme bien désirable et 'promis', son obscurité inviolable. Mais l'adresse, elle, révélée et transmise ex auditu - par ouï-dire - dévoile quelque peu la nature du lien et, dans son effectuation, le signe s'accomplit en chose même, resserrement de la promesse en prémices et pregustatio."
}

46 J.-L. Souletie, L'injonction éthique du rite chrétien, in: Habiter le monde selon le désir de Dieu. Mélanges Médevielle, éd. L. Dubrulle \& C. Fino, Paris 2015, p. 207-218 (Théologie à l'université, 35). 


\section{Theological dimension}

The experience of faith realized in the liturgy is fundamentally a paschal experience. On the one hand, because of the mystery celebrated, irrigating all celebration, and on the other hand because it deals with being able to rely on it in our everyday life. We learn, step by step, word by word, gesture after gesture, to live according to the authentic dynamism of Easter to better announce it to the world. This ceremoniality of the paschal movement thus ensures "a dispensation of the fruits of the paschal mystery of Christ" 47 because we are put in contact with the mystery itself. ${ }^{48}$ This paschal experience of faith leads us to recognize the theological dimension of ceremoniality. It refers to a "theology" based on anthropological "data" derived from processes characterizing the human being. As the Pauline formulation borrowed from the epistle to the Colossians suggests, "For in him (Christ), corporally, dwells all the fullness of divinity," in the human experience - anthropologal - holds the experience of the divine - theologal. The liturgy therefore articulates common faith and theological faith, not only in a relation of continuity, but according to a theological axis of metanoia, that is conversion to the mystery of God.49

\section{Conclusion}

Throughout this course, we proved how relevant it is to consider the ars celebrandi from the perspective of ceremoniality, in order to approach the liturgy in its most vivid reality. Starting from the liturgical action itself requires taking into account not only the means and their implementation, but also their effects. This supposes to perceive the liturgy in a continuity,

\footnotetext{
47 CEC 1076.

48 SC 102.

49 J.-Y. Hameline, La foi sur son axe fondamental, p. 12-13: “Nous parlerons d'un 'axe de la foi' pour souligner la communauté de logique et de déploiement processuels (le registre de l'identité et du destin, si l'on préfère) entre la 'foi de situation commune' et la foi religieuse et, plus précisément, la foi théologale, compte tenu, c'est évident, de la transversalité décisive introduite ici par l'aventure pascale et la révélation du Nom du Père dans le Christ."
} 
between the ritual forms used as with their signifying production. The theological reflection of Jean-Yves Hameline, based on a demanding ritual anthropology, tried to account for this continuous process. To this end, the notion of site cérémoniel remains a major tool which enables to highlight an articulation between interior and exterior that is seen as a spiritual continuity:

The 'external worship' is not a worship that is outside, but a worship action that occurs, or even that produces its externality as a sign, a testimony, an exercise..$^{50}$

In some way a double loyalty is required to follow the path opened by our predecessors. On the one hand a loyalty to the liturgical sciences themselves. Even though we no longer live in the time when we had to "make" them a way in theological reflection, we should however surely continue to deepen methodologically the use of these ancillary sciences according to a triangular conversation between Theology/Philosophy/ Anthropology..$^{51}$ Thus, they will continue to allow us to always better understand the liturgy as this "integral public worship driven by the Mystical Body of Jesus Christ, i.e. by the Chief and his members." ${ }^{2}$

On the other hand, we must invest new elaborations concerning a theology of the liturgy. ${ }^{53}$ Even if it exceeds the limits of this contribution, it is

50 J.-Y. Hameline, À la recherche d'une économie posturale, LMD $2006 \mathrm{~N}^{\circ} 247$ : “Le culte extérieur n'est pas un culte qui est à l'extérieur, mais une action de culte qui se produit, ou même qui produit son extériorité comme signe, témoignage, exercice, ce qui revient à dire qu'elle contient dans sa forme pratique une sorte d'intentionnalité anagogique qui vient articuler ce qu'il était convenu d'appeler l'intérieur et l'extérieur."

51 Cf. J. Greisch, Phénoménologie de la religion et sciences religieuses. Plaidoyer pour une 'conversation triangulaire', in: Approches scientifiques des faits religieux, dir. J. Joncheray, Paris 1997, p. 189-218 (Sciences théologiques et religieuses, 7).

$52 \mathrm{SC} 7$.

53 Cf. P. de Clerck, Une théologie de la liturgie "pour la gloire de Dieu et le salut du monde", LMD $2000 \mathrm{~N}^{\circ} 221$, p. 7-30. Various authors can be convened to draw a contrasting picture of the theological dimension of the liturgy and the way of thinking it as theology. We can mention among others: Jean Corbon, Alexander Schmemann, Jean-Jacques Von Allmen, Hermann Volk, David Fagerberg, Salvatore Marsili, Achille M. Triacca. 
necessary to point to what appears to be the contribution of a ceremonial approach to the liturgy. Going through the reflections of Hameline leads us to rethink the relationship between theology and liturgy in a form that is similar to what Achille Maria Triacca offered. Liturgy and theology are, by nature, a hermeneutic of faith lived and celebrated, of man in the "act of faith." "The two realities, theology with its diaconal dimension to the liturgy and the liturgy as lived and celebrated theology, rely on the vis vitalis fidei (= Credo Mysterio)." 54 In doing so, the theology/liturgy ratio as Prosper d'Aquitaine's classical adage states, lex orandi / lex credendi, can be reinterpreted from this intelligence of ritual and ceremonial action. It's not about adding the third term of lex agendi or lex vivendi, but about starting from the inside dynamics of the adage as faith lived and celebrated, ut legem credendi lex statuat supplicandi. As Hameline says,

Undoubtedly the best way to find, somewhat rejuvenated, the very contents and to be led to reconsider the link to others as part of a community of destiny founded on the reciprocity of places recognized and welcomed, is to understand the originality of faith as a movement, as a process, both in its source and in its end. ${ }^{55}$

Thinking thus the relation between Theology and Liturgy as hermeneutics of the believing life, makes it possible to renew a sacramentary which remains deeply linked to the hylemorphic approach which leads to the tridentine trilogy of material-shape-ministry. Indeed although Vatican II did not really make a theology of the sacraments, it did, however, inscribe them on the horizon of the Church and of the Christian life, in order to escape from a dualism between the one who receives it and the community of faith, between the sacramental moment and its celebration, between sacramental efficiencuy and validity. Hameline approach of liturgical action puts it in the entirety and the organicity of the ceremonial gesture. Its horizon is the "act-of-faith," because according to him, the theological resides in the an-

54 A. M. Triacca, «Liturgia " «ocus theologicus » ou «Theologia " Locus liturgicus ». Du dilemme à la synthèse », in: G. Farnedi, Paschale Mysterium, Studi in memoria dell'Abate Prof. Salvatore Marsili (1910-1983), traduction française par Alban Toucas OSB, Rome 1986, p. 222. 55 J.-Y. Hameline, La foi sur son axe fondamental, p. 12. 
thropological in order to arouse and reach the theology of the sacramental or believing life.

In addition, starting from a theology of ceremoniality, granting the anthropological request, we could elaborate a sacramentality able to unfold the mystery of God and of the faith, holding together the sacramental moment and its ceremonial exposition. In a way, it's a question of going beyond Chauvet, ${ }^{56}$ by putting his sacramental hermeneutic of Christian life from the symbol in the ceremonial and liturgical action as an epiphany of the Church in prayer in the words of St Jean-Paul II.

\section{Streszczenie}

\section{Teologia celebracji. Refleksja nad ars celebrandi 5o lat po Vaticanum II}

Zaproszenie niniejszego sympozjum do wglądu w historię różnych ośrodków nauczania i refleksji dotyczącej liturgii i jej wymiaru teologicznego jest okazja, by nie tylko wspomnieć mistrzów, którzy nas poprzedzili, ale zobaczyć, dokąd ich refleksja teologiczna prowadzi nas dzisiaj. Nawiązując do słów Bernarda z Chartres z XII wieku, powinniśmy uznać, że ,jesteśmy karłami, siedzącymi na ramionach gigantów, i tego, że widzimy więcej i dalej niż oni, nie zawdzięczamy przenikliwości naszego wzroku ani naszej wielkości, ale temu, że zostaliśmy przez nich wzniesieni".

Śledząc drogę refleksji teologicznej Wyższego Instytutu Liturgicznego na Wydziale Teologicznym Instytutu Katolickiego w Paryżu, dostrzegamy, jak intuicje teologiczne i akademickie, które poprzedziły jego utworzenie w 1956 roku, w ślad za ruchem liturgicznym XX wieku, pozwoliły wypracować warunki powstania teologii liturgii począwszy od odnowienia obrzędowości. Innymi słowy, jednym $\mathrm{z}$ aktualnych zadań teologii liturgii jest refleksja nad tym, jak liturgia pozwala realizować autentyczny akt wiary.

Sytuując liturgię w orbicie objawienia chrześcijańskiego i budowania Kościoła (KL 2), Sobór Watykański II zakorzenił ją mocniej w wykonywaniu kapłańskiego

56 Cf. P. Prétot, Les sacrements comme "célébration de l'Église »: l'impact de la liturgie sur la théologie sacramentaire, in: P. Bordeyne, B. T. Morril, Les sacrements, révélation de l'humanité de Dieu, Paris 2008, p. 55-73 (Cogitatio Fidei, 263). 
For the theology of celebration. Thinking about ars celebrandi 50 years after Vatican II $\mid 261$

urzędu Chrystusa i uznał jej wymiar sakramentalny: „każdy obchód liturgiczny, jako dzieło Chrystusa-Kapłana i Jego Ciała, czyli Kościoła, jest czynnością w najwyższym stopniu święta, a żadna inna czynność Kościoła nie dorównuje jej skuteczności z tego samego tytułu i w tym samym stopniu" (KL 7). Tym niemniej, jeśli sakramenty doczekały się refleksji w świetle liturgicznego działania Kościoła, słabe są jeszcze definiowanie i charakterystyka elementów sakramentalności samego aktu wiary, który realizuje się w kontekście liturgii. Śledząc myśl ojca Patricka Prétota, chcielibyśmy wyjaśnić, jak pozwoli to przemyśleć liturgię jako autentyczną „formę życia" wiary chrześcijańskiej. 
